\title{
Removal of Phenol in Batch Culture by Pseudomonas putida AP11, AP9, AP6 and AP7 Isolated from the Aromatic Hydrocarbon Contaminated Soils
}

\author{
M. A. I. Khan' ${ }^{1}$ A. N. M. Fakhruddin ${ }^{1 *}$, S. A. Jame', M. S. Sultana ${ }^{1}$, and M. K. Alam² \\ ${ }^{1}$ Department of Environmental Sciences, Jahangirnagar University, Dhaka-1342, Bangladesh \\ ${ }^{2}$ Institute of Food \& Radiation Biology, Atomic Energy Research Establishment, Savar, Dhaka- \\ 1344, Bangladesh
}

Received 20 October 2010, accepted in final revised form 7 March 2011

\begin{abstract}
Phenol widely used in industries, are of growing concern owing to their toxicity and wide distribution in industrial wastes. The aims of the study were to characterize some of the locally isolated bacteria and to develop suitable methods for the degradation of phenol using them. Locally isolated AP11, AP9, AP6 and AP7 were identified as Pseudomonas putida using the classical methods. Pseudomonas putida AP11 and AP9 were able to remove 600 ppm phenol completely, but Pseudomonas putida AP6 and AP7 were able to remove 400 ppm phenol completely. The maximum degradation rates for freely suspended culture of Pseudomonas putida AP11, AP9, AP6, AP7 were 10.83, 10.42, 8.33, and $8.33(\mathrm{ppm} / \mathrm{h})$ respectively. The isolates AP11, AP9, AP6 and AP7 can be used to wastewater containing phenol in effluent treatment systems.
\end{abstract}

Keywords: Aromatic hydrocarbon; Carbon source; Contaminated soil; Phenol; Pseudomonas.

(c) 2011 JSR Publications. ISSN: 2070-0237 (Print); 2070-0245 (Online). All rights reserved.

doi:10.3329/jsr.v3i2.6339 J. Sci. Res. 3 (2), 367-374 (2011)

\section{Introduction}

Phenols are toxic to human beings and affect several biochemical functions [1]. Phenol is a listed priority pollutant by the U.S. Environmental Protection Agency [2] and is considered to be a toxic compound. The toxicity of phenol has been widely documented and their disastrous effect toward human and environment is a great concern [3-5]. The greatest potential source of exposure to phenol is in the occupational setting, where phenol is used in manufacturing processes. People are also exposed via consumer products, such as medicines and lotions, and some foods and tobacco smoke. Phenol has been found in drinking water [2]. Phenol is currently removed by different methods such as precipitation/coagulation, osmosis, ion-exchange, ultrafiltration, electrodialysis, electrochemical degradation, floatation, etc., which are costly and inefficient. These current

\footnotetext{
*Corresponding author: a.fakhruddin2@mail.dcu.ie
} 
treatments often produce other toxic end products, requiring further processing steps [6-8]. On the other hand, biodegradation has been studied as an alternative approach due to the low costs associated with this option, as well as the possibility of complete mineralization of the xenobiotic [9]. Phenol biodegradation has been studied detail using pure and mixed cultures of suspended bacteria [10-11]. Phenol and other phenolic compounds are common constituents of many industrial effluents and suitable microorganism based process need to be developed for the effective degradation of phenol and then the effluents could be disposed safely [12].

The aim of this study was to identify and characterize the potential phenol degrading bacteria, isolated from the contaminated sites and their ability to degrade various concentrations of phenol when supplied as the sole carbon source was investigated.

\section{Materials and Methods}

\subsection{Test organisms and identification}

Isolates were obtained from Microbiology and Industrial Irradiation Division, Institute of Food and Radiation Biology, Atomic Energy Research Establishment, Savar, Dhaka, Bangladesh. The organisms were previously isolated from soils of aromatic compound contaminated sites. The isolates were identified using cultural, morphological characteristics and biochemical tests according to methods described in Bergey's Manual of Systematic Bacteriology [13]. The bacteria were maintained on phenol agar medium and stored at $4^{0} \mathrm{C}$ for around 1 month and then sub-cultured.

\subsection{Pseudomonas minimal medium}

The ingredients of minimal medium [14] were dissolved in distilled water and the $\mathrm{pH}$ was adjusted to 7.0 with $2 \mathrm{M} \mathrm{NaOH}$. The composition of minimal medium per litre were as follow: $\left(\mathrm{KHPO}_{4}, 4.36 \mathrm{~g}\right.$; $\mathrm{NaH}_{2} \mathrm{PO}_{4}, 3.45 \mathrm{~g}$; $\mathrm{MgSO}_{4}, 0.912 \mathrm{~g} ; \mathrm{NH}_{4} \mathrm{Cl}, 1.0 \mathrm{~g}$; $\left.\mathrm{pH}, 7\right)$. Trace salt solution was added at a concentration of $1 \mathrm{ml}$ per litre. The composition of trace salt solution per $100 \mathrm{ml}$ was as follows: $\mathrm{CaCI}_{2} \cdot 2 \mathrm{H}_{2} 0,4.77 \mathrm{~g}$; $\mathrm{FeSO}_{4} \cdot 7 \mathrm{H}_{2} 0,0.37 \mathrm{~g}$; $\mathrm{CoCl}_{2} \cdot 6 \mathrm{H}_{2} \mathrm{O}$, $0.37 \mathrm{~g} ; \mathrm{MnCl}_{2}, 0.19 \mathrm{~g} ; \mathrm{NaMoO}_{4} \cdot 2 \mathrm{H}_{2} 0,0.02 \mathrm{~g}$.

\subsection{Phenol agar}

Bacteriological agar at a concentration of $1.5 \%(\mathrm{w} / \mathrm{v})$ was added to the minimal medium. Following sterilization by autoclaving, the medium was allowed to cool. Immediately prior to pouring phenol was added to the medium to give the appropriate concentrations. Phenol broth was used for biodegradation studies, the composition of which was exactly similar to the phenol agar except that no agar was added to it.

\subsection{Cultural conditions for biodegradation studies}

Isolates were grown in nutrient broth for 24 hours, centrifuged at $5000 \mathrm{rpm}$ for 10 minutes and washed twice with potassium phosphate buffer. Five $\mathrm{ml}$ of bacterial suspension 
( $10^{7}$ cells/ml) was used to inoculate $95 \mathrm{ml}$ sterile minimal medium [14] containing phenol in $250 \mathrm{ml}$ conical flasks. After inoculation, flasks were incubated in an orbital shaker at $120 \mathrm{rpm}$ at $37^{\circ} \mathrm{C}$. Control flasks were run in parallel. Samples were aseptically removed at regular intervals and analyzed for growth and substrate removal. The study period for phenol was 0-96 h.

\subsection{Measurement of the growth of bacterial cells}

Growth of the bacterial cells was monitored turbidimetrically by measuring the optical density (OD) at $660 \mathrm{~nm}$ using a UV visible spectrometer.

\subsection{Chemical Analyses}

Concentrations of phenol were determined by colorimetric method using 4aminoantipyrene based on the procedure detailed in standard methods for the examination of water and wastewater [15].

\section{Results and Discussion}

\subsection{Identification and characterization of bacterial isolates}

Cultural and morphological characteristics of the isolates are shown in Table 1. The cell characteristics were noted following cultivation on nutrient agar at $30^{\circ} \mathrm{C}$. All the isolates were gram negative, motile, non-spore forming and rod shaped. None of them showed acid fast staining. A variety of biochemical tests were performed on all the strains to

Table 1. Colony characteristics and microscopic observation of the bacteria isolated from aromatic hydrocarbon contaminated soils.

\begin{tabular}{lllll}
\hline \multirow{2}{*}{$\begin{array}{l}\text { Colony character/ } \\
\text { microscopic observation }\end{array}$} & \multicolumn{4}{c}{ Isolates } \\
\cline { 2 - 5 } Size & AP11 & AP9 & AP6 & AP7 \\
Color & Cmall & Moderate & Moderate & Small \\
Colony shape & Colorless & Buff & Buff & Colorless \\
Elevation & Circular & Circular & Circular & Circular \\
Opacity & Convex & Convex & Convex & Convex \\
Cell shape & Translucent & Opaque & Opaque & Translucent \\
Gram reaction & Rod & Rod & Rod & Rod \\
Spore staining & - & - & - & - \\
Motility & - & - & - & - \\
Acid fast staining & - & & & - \\
\hline$+=$ positive reaction, & $-=$ negative reaction & &
\end{tabular}


enable their identification and the results are shown in Table 2. In the biochemical test, all of the isolates were found as oxidase and catalase positive. Production of $\mathrm{H}_{2} \mathrm{~S}$ and urease were not observed for any of the isolates. In Voges proskauer and methyl red test, different response was observed.

Table 2. Biochemical tests of four bacterial isolates.

\begin{tabular}{|c|c|c|c|c|c|c|c|c|c|c|}
\hline \multirow[t]{2}{*}{ Isolates } & \multicolumn{10}{|c|}{ Biochemical Tests } \\
\hline & $\begin{array}{l}\text { Oxidase } \\
\text { test }\end{array}$ & $\begin{array}{l}\text { Catalase } \\
\text { test }\end{array}$ & $\begin{array}{l}\text { Indole } \\
\text { production }\end{array}$ & $\begin{array}{l}\text { Voges } \\
\text { proskauer }\end{array}$ & $\begin{array}{l}\text { Methyl } \\
\text { red }\end{array}$ & $\begin{array}{l}\text { Tween } \\
\text { hydrolysis }\end{array}$ & $\begin{array}{l}\text { Starch } \\
\text { hydrolysis }\end{array}$ & $\mathrm{H}_{2} \mathrm{~S}$ & $\begin{array}{l}\text { Urease } \\
\text { test }\end{array}$ & Citrate \\
\hline AP11 & + & + & - & + & - & - & - & - & - & - \\
\hline AP9 & + & + & - & - & + & - & - & - & - & - \\
\hline AP6 & + & + & - & - & + & - & - & - & - & - \\
\hline AP7 & + & + & - & + & - & - & - & - & - & - \\
\hline
\end{tabular}

$+=$ positive reaction, $-=$ negative reaction

A wide range of sugar utilization was also observed by all of the isolates (Table 3). Isolates AP11 and AP9 were able to grow on most of the sugars except lactose. The AP6 grew in the presence of four sugars out of ten while the AP7 utilized six sugars.

Table 3. Carbohydrate utilization by four isolates.

\begin{tabular}{|c|c|c|c|c|}
\hline \multirow[t]{2}{*}{ Carbohydrate } & \multicolumn{4}{|c|}{ Isolates } \\
\hline & AP11 & AP9 & AP6 & AP7 \\
\hline Fructose & + & + & - & - \\
\hline Arabinose & + & + & - & - \\
\hline Glucose & + & + & + & + \\
\hline Galactose & + & + & + & + \\
\hline Maltose & + & + & - & - \\
\hline Sorbital & + & + & + & + \\
\hline Manitol & + & + & - & + \\
\hline Sucrose & + & + & - & + \\
\hline Xylose & + & + & + & + \\
\hline Lactose & - & - & - & - \\
\hline
\end{tabular}

Comparing the cultural, morphological and biochemical characteristics of isolates with the properties listed in the Bargey,s Manual for systematic Bacteriology [13], it was found that all of the isolates belong to Pseudomonas putida. Pseudomonas putida are regarded as one of the most common species of phenol degrading bacteria isolated from contaminated sites [16-19]. The ability of this species particularly to utilize aromatic hydrocarbons has been widely documented [20-21]. It was also able to use a wide 
diversity of carbon energy substrates and this together with their ability to compete effectively with other bacteria, is undoubtedly responsible for their dominance [22]. Pseudomonas putida EKII, Pseudomonas cepacia G4, Pseudomonas putida Q5, Pseudomonas putida MTCC were investigated as phenol degrader as well as all of them were non pathogenic [16, 23-26].

\subsection{Growth of pseudomonas putida isolates and their degradation capacity in liquid culture media containing phenol in different concentrations}

All the organisms were grown in the liquid culture containing $100 \mathrm{ml}$ minimal medium with various concentrations of phenol (400-800 ppm). The results of phenol degradation and their corresponding removal rates and removal efficiency are presented in Fig. 1 and Table 4.
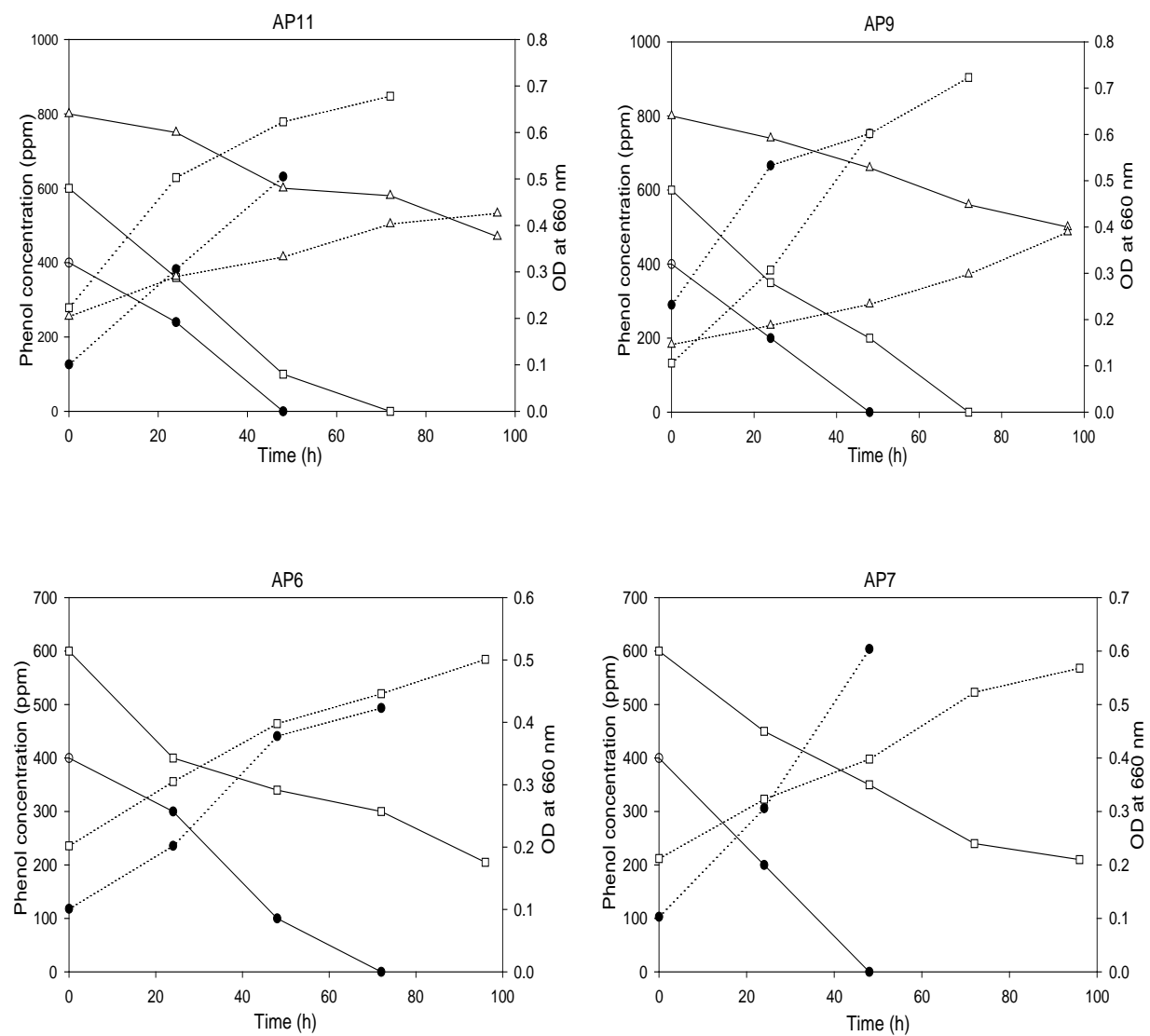

Fig. 1. The removal of various concentrations of (400 - $800 \mathrm{ppm})$ phenol by Pseudomonas species when supplied as the sole sources of carbon and energy (solid line represents degradation and corresponding broken line represents growth). 


\section{Removal of Phenol}

AP11 was found to be the most effective bacteria comparing with the others isolates. Complete removal of 400 and 600 ppm of phenol was observed by the organism. Removal efficiency was higher with the progressing growth. Highest bacterial growth (OD 0.507 at $660 \mathrm{~nm}$ ) was observed at $72 \mathrm{~h}$. However, complete removal of $800 \mathrm{ppm}$ was not observed. It was possible to remove about $41.25 \%$ within the time $96 \mathrm{~h}$ and the bacterial growth was increasing slowly with removal of phenol (Table 4). Almost similar patterns of growth, phenol degradation, removal rate and removal efficiency were observed for the isolate AP9.

Pseudomonas putida AP6 degraded 400 ppm of phenol completely within $72 \mathrm{~h}$. Complete degradation of $600 \mathrm{ppm}$ phenol was not achieved within $96 \mathrm{~h}$. It was possible to degrade only $66 \%$. The bacterial growth was highest at $72 \mathrm{~h}$ for $400 \mathrm{ppm}$ phenol. The increasing growth was not in similar fashion at $600 \mathrm{ppm}$ compared to $400 \mathrm{ppm}$. Maximum growth (OD 0.370) was found at $96 \mathrm{~h}$ with $600 \mathrm{ppm}$ phenol. Maximum removal rate was 8.33 (Table 4). The isolates AP7 also showed almost similar patterns of growth, phenol degradation, removal rate and removal efficiency as observed for AP6.

Table 4. Maximum concentration of phenol degradation, degradation time, and growth and removal efficiency of different isolates of Pseudomonas putida AP11, AP9, AP7 and AP6.

\begin{tabular}{|c|c|c|c|c|c|c|}
\hline Isolate & $\begin{array}{l}\text { Phenol conc. } \\
(\mathrm{ppm})\end{array}$ & $\begin{array}{l}\text { Max. deg. } \\
\text { (ppm) }\end{array}$ & $\begin{array}{l}\text { Time } \\
\text { (h) }\end{array}$ & $\begin{array}{l}\text { Growth } \\
\text { (OD at } 660 \\
\mathrm{~nm})\end{array}$ & $\begin{array}{l}\text { Deg. rate } \\
\text { at } 24 \mathrm{~h} \\
(\mathrm{ppm} / \mathrm{h})\end{array}$ & $\begin{array}{l}\text { Removal } \\
\text { efficiency } \\
\text { (\%) }\end{array}$ \\
\hline \multirow[t]{3}{*}{ AP11 } & 400 & 400 & 48 & 0.304 & 10.83 & 100 \\
\hline & 600 & 600 & 72 & 0.507 & 10.00 & 100 \\
\hline & 800 & 330 & 96 & 0.331 & 2.08 & 41.25 \\
\hline \multirow[t]{3}{*}{ AP9 } & 400 & 400 & 48 & 0.456 & 8.33 & 100 \\
\hline & 600 & 600 & 72 & 0.435 & 10.42 & 100 \\
\hline & 800 & 300 & 96 & 0.251 & 2.50 & 37.5 \\
\hline \multirow[t]{2}{*}{ AP6 } & 400 & 400 & 72 & 0.276 & 4.17 & 100 \\
\hline & 600 & 395 & 96 & 0.370 & 8.33 & 65.83 \\
\hline \multirow[t]{2}{*}{ AP7 } & 400 & 400 & 48 & 0.338 & 8.33 & 100 \\
\hline & 600 & 390 & 96 & 0.403 & 6.25 & 65 \\
\hline
\end{tabular}

It was reported that Pseudomonas putida CP1 is capable to remove $600-800 \mathrm{ppm}$ of phenol, Pseudomonas putida A(a) also degraded 600 ppm phenol within $24 \mathrm{~h}$ and 800 ppm phenol within $48 \mathrm{~h}$ [18]. The bacterial growth varied with time and concentration of phenol. The Pseudomonas sp. A4CP2, exhibited the highest growth (OD = 0.55) growing on 800 ppm phenol [19]. A number of bacteria have been evaluated for their usefulness in controlling phenol, a hazardous pollutant, which is produced in oil refineries, petrochemical plants, pharmaceutical industries etc. [27-29].The isolates AP11, AP9, AP6 and AP7 were capable to degrade phenol at a concentration very much similar to other 
reported strains, therefore, the isolates can be used to wastewater containing phenol in effluent treatment systems.

\section{Conclusions}

Four isolates, namely AP11, AP9, AP6 and AP7 obtained from aromatic hydrocarbon contaminated soils were identified as Pseudomonas putida. Complete degradation of 600 ppm phenol was found for isolates AP11 and AP9, but complete degradation of 400 ppm phenol was found for isolates AP6 and AP7. The maximum degradation rates for suspended culture of Pseudomonas putida AP11, AP9, AP6, AP7 were 10.83, 10.42, 8.33, and $8.33(\mathrm{ppm} / \mathrm{h})$, respectively.

\section{References}

1. A. Nuhoglu and B. Yalcin, Process Biochemistry 40, 233 (2005).

2. US-EPA. Toxicological Review of Phenol (CAS No. 108-95-2). U.S. Environmental Protection Agency, Washington D.C. (2002).

3. A. M. Hannaford and C. Kuek, J. Indust. Microbio. Biotech. 22, 121 (1999). doi:10.1038/sj.jim.2900617

4. K. C. Chen, Y. H. Lin, W. H. Chen and Y. C. Liu, Enzym. Microb. Tech. 3, 490 (2002). doi:10.1016/S0141-0229(02)00148-5

5. M. B. Prieto, A. Hidalgo, J. L. Serra and M. J. Lama, J. Biotech. 97, 1 (2002). doi:10.1016/S0168-1656(02)00022-6

6. W. Kobayashi and B. E. Rittmann, Environ. Sci. Tech. 16, 170 (1982). doi:10.1021/es00097a002

7. V. K. Gupta, S. Sharma, I. S. Yadav and D. Mohan, J. Chem. Tech. Biotech. 71, 180 (1998). doi:10.1002/(SICI)1097-4660(199802)71:2<180::AID-JCTB798>3.0.CO;2-I

8. S. Rengaraj, M. Seung-Hyeon, R. Sivabalan, B. Arabindooand, and V. Murugesan, Waste Management 22, 543 (2002). doi:10.1016/S0956-053X(01)00016-2

9. I. Singleton, J. Chem. Tech. Biotech. 59, 9 (1994). doi:10.1002/jctb.280590104

10. P. J. Allsop, Y. Chisti, M. Moo-Young and G. R. Sullivan, Biotech. Bioeng. 41, 572 (1993). doi:10.1002/bit.260410510

11. S. J. Wang, and K. C. Loh, Enzyme Microbial Tech. 25, 177 (1999). doi:10.1016/S0141-0229(99)00060-5

12. S. M. Borghei and S. H. Hosseini, Process Biochemistry 39, 1177(2004). doi:10.1016/S0032-9592(02)00195-4

13. R. E. Buchanan and N. E. Gibbons, Bergey's Manual of Determinative Bacteriology, $8^{\text {th }}$ edition (The Williams and Wilkins Company, Baltimore, 1984).

14. C. Goulding, C. J. Gillen and E. Bolton, J. Appl. Bacteriology, 65, 1 (1988).

15. APHA, Standard Methods for the Examination of Water and Wastewater (A. E. Greenberg, L. S. Clesceri and A. D. Eaton eds.), 20 $0^{\text {th }}$ edn, pp. 5.31-5.33. APHA, AWWA \& WEF (1998).

16. C. Hinteregger, R. Leitner, M. Loidl, A. Ferschl and F. Streichsbier, Appl. Microb. Biotech. 37, 252 (1992). doi:10.1007/BF00178180

17. F. Fava, P. M. Armenante and D. Kafkewitz, Lett. Appl. Microbio. 21, 307 (1995). doi:10.1111/j.1472-765X.1995.tb01066.X

18. M. A. Z. Chowdhury, A. A. Mahin, and A. N. M. Fakhruddin, Bangladesh J. Microbio. 23, 29 (2006).

19. S. A. Jame, A. K. M. Rashidul Alam, M. Khorshed Alam and A. N. M. Fakhruddin, Bangladesh Journal Microbiology 25, 41 (2008). 


\section{Removal of Phenol}

20. R. M. Atals, Petroleum Microbiology (Macmillans Inc., New York, 1984).

21. D. T. Gibson. and V. Subramanian, Microbial Degradation of Organic Compounds. Microbiology Series, vol. 13 (Marcel Dekker, Inc. New York, USA, 1984) pp. 181-252.

22. G. Hamer, Comprehensive Biotechnology, M. Moo-Young (ed.), Vol. 3 (Pergamon Press, Oxford, 1995) p. 819.

23. S. Y. Dapaah, and G. A. Hill, Biotech. Bioeng. 40, 1353 (1992). doi:10.1002/bit.260401109

24. B. R. Folsom, P. J. Chapman and P. H. Pritchard, Appl. Environ. Microbiology 56, 1279 (1990).

25. W. Sokol, Biotech. Bioeng. 30, 921 (1987). doi:10.1002/bit.260300802

26. K. Bandyopadhyay, D. Das, and B. R. Maiti, Bioprocess Engineering 18, 373 (1998).

27. R. C. Bayly and G. L. Wigmore, J.l Bacteriology 113, 1112 (1973).

28. S. P. Antai and D. L. Crawford, Canadian J. Microbiology 29, 142 (1983). doi:10.1139/m83-022

29. G. Gurujeyalakshmi and P. Oriel, Appl. Environ. Microbiology 55, 500 (1989). 